\title{
PNA Biosensors for Nucleic Acid Detection
}

\author{
Joseph Wang \\ Department of Chemistry and Biochemistry, \\ New Mexico State University, Las Cruces, NM 88003, USA
}

\begin{abstract}
Biosensor devices, based on the conversion of nucleic acid recognition reactions into useful electrical signals, offer considerable promise for DNA diagnostics. The unique hybridization properties of solution-phase PNA can be extrapolated onto transducer surfaces in connection with the design of remarkably specific DNA biosensors. This article reviews the development of PNA biosensors, and discusses common PNA-biosensing protocols along with their prospects in DNA biosensor technology.
\end{abstract}

\section{Introduction}

Biosensors are small devices employing biological recognition properties for a selective bioanalysis. Such devices rely on the intimate coupling of a biological recognition element with a physical transducer (such as an electrode or fiber optic). The goal is to convert the biological recognition event into a useful electrical signal, proportional to the concentration of the target analyte. By combining the sample handling and measurement steps, biosensors eliminate the need for the sample preparation and hence offer great promise for numerous on-site analytical applications (for which rapid, low-cost measurements are highly desired). A high level of sophistication is commonly employed to mass produce easy-to-use, miniaturized, and often disposable devices. Depending on the nature of the biological process, two general categories of biosensing devices may be distinguished: biocatalytic sensors (based primarily on immobilized enzymes) and affinity devices (utilizing antibodies, receptors and nucleic acids).

The use of nucleic acid recognition layers represents a relatively new and exciting area in biosensor technology (1-3). In particular, DNA hybridization biosensors offers considerable promise for obtaining the sequence-specific information in a simpler, faster and cheaper manner, compared to traditional hybridization assays. Such devices thus hold an enormous potential for decentralized clinical diagnosis of genetic or infectious diseases, for the rapid detection of food-contaminating organisms, and for on-site forensic investigations or environmental testing.

The basis for these nucleic-acid hybridization devices is the DNA base pairing. Accordingly, they usually rely on the immobilization of a 25-40 mer short synthetic oligonucleodide (the 'probe'), whose sequence is complementary to sought-for targets, onto the physical transducer. Exposure of the sensor to a sample containing the target results in the formation of the hybrid on the surface. Electrochemical, optical or frequency monitoring of this duplex formation can thus result in a useful analytical signal.

As with other types of biosensors, high selectivity is crucial for the success of DNA hybridization devices. The specificity of these genosensors (i.e., their ability to respond to the target sequence in the presence of non-complementary strands) 
depends primarily on the selection of the probe, and secondarily upon the hybridization conditions (mainly the temperature). To date, however, most DNA biosensors are not capable of selectively discriminating against single-base mismatches, as desired for example, for the detection of disease-related point mutations. The ability to recognize a change in a single nucleotide thus represents a major challenge for DNA biosensor technology. Accordingly, a drastically different approach (relying on the use of new probes) is desired to impart higher selectivity onto nucleic-acid biosensors.

The introduction of peptide nucleic acid (PNA) has opened up exciting opportunities for DNA biosensors. The unique structural, hybridization, and recognition features of solution-phase PNA $(12,13)$ can be readily extrapolated onto transducer surfaces in connection with the design of DNA biosensors. Such use of surface-confined PNA recognition layers imparts remarkable sequence specificity onto DNA biosensors and offers other attractive advantages (including greater latitude in the selection of experimental conditions). The greatly improved distinction between closely related sequences accrued from the use of PNA were first realized in connection with electrochemical transduction of the PNA/DNA hybridization event (4), and subsequently using other types of biosensors $(5,6)$. This article reviews the status of PNA-based biosensors, and their prospects for future DNA diagnostics.

\section{Protocols}

The development of PNA hybridization biosensors requires proper attention to the various steps on the assay protocol. Such protocol commonly consists of three steps: immobilization of the PNA probe, the hybridization event, and detection of the duplex formation (Figure 1). Systematic optimization of each these steps is essential for meeting the requirements of high sensitivity, specificity, and speed. Depending upon the sensor configuration and mode of operation, such bioassays can be accomplished in a flow-through system or in a batch-type design.

The immobilization step should result in a readily accessible and yet highly stable PNA probe. While the use of PNA allows the use of very short probes, statistical considerations favor the use of probes longer than 20-mer. Depending upon the nature of the physical transducer, various schemes can be used for attaching the PNA probe to the surface. These include the use of thiolated PNA for self assembly onto gold transducers (gold electrodes or gold-coated piezoelectric crystals), covalent linkage to the gold surface via a functional alkanethiol-based monolayers, the use of biotylated PNA for complex formation with a surface-confined avidin or strepavidin, covalent (carbodiimide) coupling to functional groups on carbon electrodes, or a simple adsorption onto carbon surfaces. The construction of highdensity arrays of PNA probes would require the use of microjet deposition technology, involving the dispension of picoliter volumes onto discrete locations on the chip.

The use of PNA probes also offers greater latitude in the selection of the hybridization conditions (compared to the use of ssDNA layers). Yet, attention should be given to the optimization of parameters influencing the kinetics and efficiency of the interfacial PNA-DNA duplex formation. In addition to solution conditions, one should consider the hybridization temperature (for tuning the selectivity) and the hybridization time (for lowering the detection limits).

Depending on the type of device, the hybrid formation can be accomplished in connection with optical, electrochemical or frequency measurements. In most electrochemical and fiber-optic devices the formation of the duplex is detected by exposing it to a solution of suitable (redox- or optically-active) indicator, that preferentially binds to the hybrid. The increased voltammetric or fluorescent response of the indicator thus serves as the hybridization signal. Different hybridization markers may be desired for PNA biosensors in view of the different binding affinities 


\section{PROBE}

IMMOBILZATION

TARGET

HYBRIDIZATION
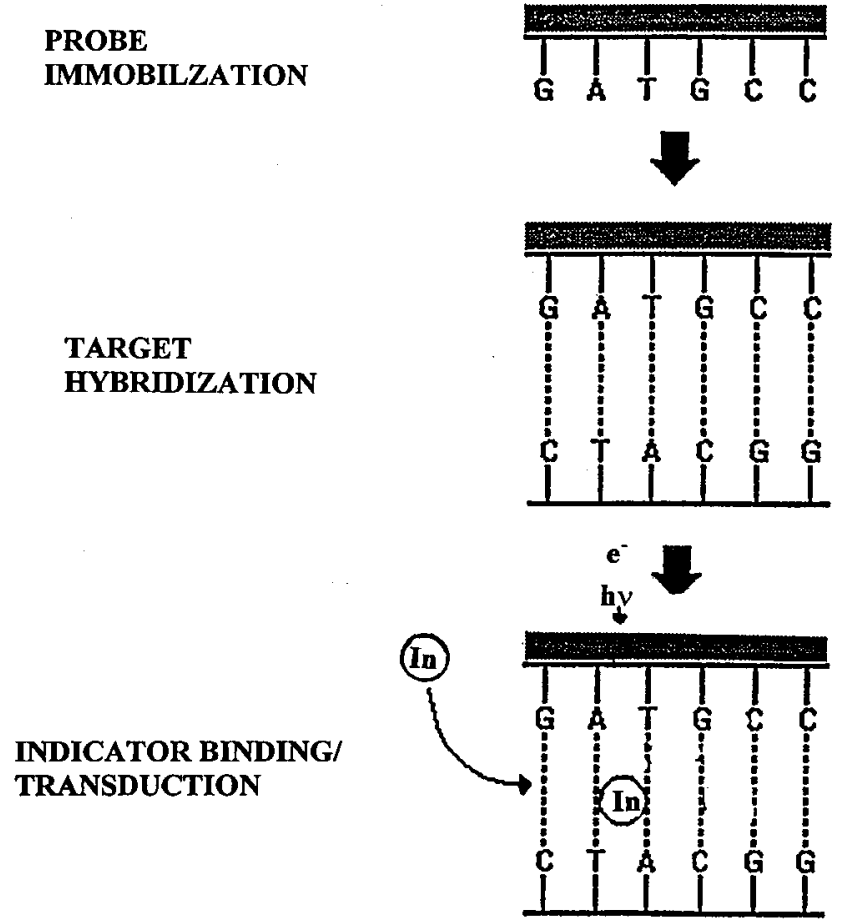

Figure 1. Common steps in sequence-specific hybridization biosensors: probe immobilization, hybridization event, and indicator association and detection.

of small molecules with PNA-DNA and DNA-DNA hybrids. Built-in (redox or fluorescent) labels, covalently attached to the PNA oligomer, may offer an attractive alternative.

The development of simpler indicator-free detection schemes may further improve the utility of PNA-based biosensors. New detection schemes, relying on the different nature of the PNA backbone, may lead to novel indicator-free strategies. For example, various electrochemical strategies may be used for detecting the sugar moiety of the hybridized DNA target (in the absence of such moiety in PNA). One may also rely on the intrinsic electroactivity of the target guanine bases for an indicator-free detection in connection to the use of guanine-free (inosine-substituted) PNA probes. An elegant work from Oak-Ridge National Laboratory demonstrated a non-labeling mass-spectroscopic hybridization detection based on monitoring the phosphorous backbone of the DNA target (6). Because the immobilized PNA probe does not have any phosphorous, the phosphorous signal can be used for detecting the hybridized DNA. Excellent discrimination between complementary and noncomplementary sequences, including increased discrimination against single point mutations has been reported in this study. Laser-based fluorescence detection, involving the use of two PNA probes (each labeled with a different dye) offered remarkably low detection limits down to the single molecule level (7). Indicator- 
free biosensing of PNA-DNA hybridization - with signals generated directly from the binding event - can be accomplished also by using surface plasmon resonance (SPR) spectroscopy (8) or quartz crystal microbalance (QCM) (5) measurments. The latter is described in the following example.

The different (higher) thermal stability of PNA-DNA duplexes requires reassessment of the regeneration conditions used for 'removing' the bound target DNA. Faster surface renewal may be achieved mechanically in connection to polishable probe-confined composite materials (9). The use of single-use (disposable) biosensors obviates the need for sensor regeneration.

\section{Example}

The remarkable mismatch discrimination capability of PNA based biosensors has been illustrated in connection to the use of quartz crystal microbalance transducer (5). The QCM is an extremely sensitive mass-sensitive sensing device, that allows dynamic (indicator-free) monitoring of the PNA-DNA hybridization event. It consists of an oscillating crystal with the PNA probe immobilized on its surface. The increase in mass, associated with the hybridization/binding reaction, results in a decrease of the oscillating frequency. The resulting PNA/QCM device thus couples the high sensitivity of QCM transducers with the inherent specificity of the PNA recognition reaction. The latter has been illustrated for the detection of a single-base alteration related to a frequent point mutation in the $p 53$ gene (a mutation found in many types of cancer cell).

For this purpose, the quartz crystal has been held at the bottom of a 2-ml glass cell (with its upper surface exposed to the solution). The crystal has been connected to a frequency counter, interfaced to a microcomputer. The gold-plated surface of the crystal has been modified by a spontaneous self-assembled process of a 15-mer thiolated PNA (containing an ethylene glycol linker). Such coupling of hydrophillic linker with a dense surface layer greatly minimizes nonspecific adsorption effects.

In a typical experiment, the target DNA is added to the stirred hybridization solution (after the stabilization of the baseline frequency). The decrease in the frequency, associated with the PNA-DNA hybridization event is monitored in real time (Figure 2). Depending upon the hybridization kinetics, a steady-state signal is reached within 1-5 min. The resulting frequency change $(\Delta \mathrm{F})$ thus serves the hybridization signal (with quantitation being accomplished with the aid of a preprepared calibration plot). Similar additions of non-complementary strands can be used for assessing the sensor specificity.

\section{Discussion and Future Prospects}

Recent studies have illustrated that the unique properties displayed by solutionphase PNA oligomers can be extrapolated onto transducer surfaces in connection with the design of highly selective DNA biosensors. Such use of DNA mimics thus opens up exciting opportunities for DNA diagnostics. The remarkable mismatch discrimination is coupled to operation over a wide range of hybridization conditions. The drastically different structure and behavior of PNA have important implications not only upon the hybridization conditions, but offer also new opportunities for designing new detection schemes. While PNA probes offer remarkable distinction between closely related sequences, attention should still be given to the elimination of non-specific adsorption effects and to the detection of sequences in large natural DNA fragments. The different charges of PNA and DNA and the marked difference in their adsorption behavior may also be exploited for minimizing non-specific DNA adsorption via a judicious choice of the electrode potential for removing interfering species (10)

High-density PNA arrays (containing the genetic information on a miniaturised 


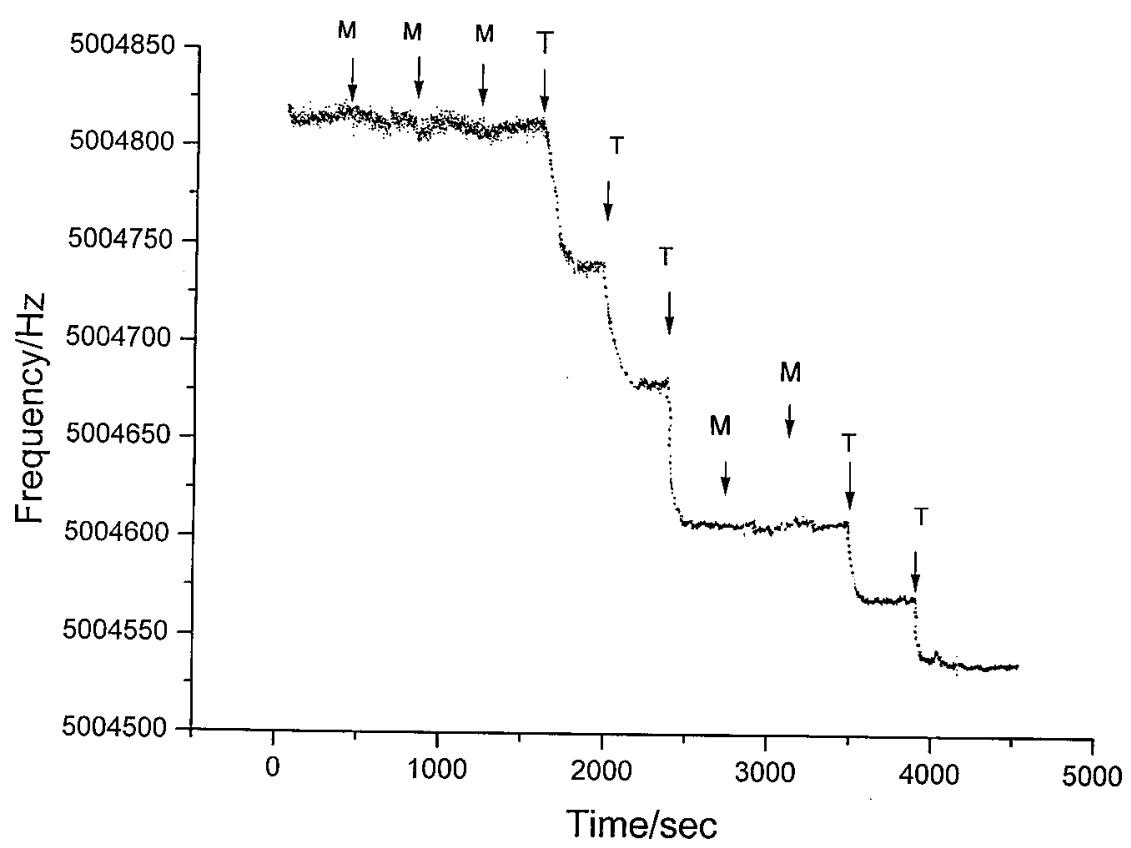

Figure 2. Frequency-time response of a PNA/QCM to additions of the target (T) and mismatch (M) oligonucleotides. The hybridization event results in decreased frequency, reflecting the increased mass of the crystal.

silicon chip) should further enhance the discriminative power of nucleic acid hybridization tests, and would allow high throughput detection of multiple sequences in a single experiment. Arrays of up to 1000 PNA oligomers of individual sequences were recently synthesized on polymeric membranes (11). Coupling such microfabricated arrays with micro-machined (on-chip) PCR amplification units, and with compact easy-to-use instruments, will greatly facilitate the realization of routine decentralized DNA testing. These and other research and commercialization efforts will surely make PNA-derived biosensors extremely useful tools in bioanalytical chemistry.

\section{References}

1. Mikkelson, S.R. 1996. Electrochemical biosensors for DNA sequence detection. Electroanalysis. 8:15.

2. Yang, M., McGovern, M.E., and Thompson, M. 1997. Genosensor technology and the detection of interfacial nucleic acid chemistry. Anal. Chim. Acta 346: 259.

3. Wang, J., Rivas, G., Cai, X., Palecek, E., Nielsen, P. E., Shiraishi, H., Dontha, N., Luo, D., Parrado, C., Chicharro, M., Farias, P.A.M., Valera, F., Grant, D., Ozsoz, M., and Flair, M. 1997. DNA electrochemical biosensors for environmental monitoring. A review. Anal. Chim. Acta 347: 1.

4. Wang, J., Palecek, E., Nielsen, P., Rivas, G., Cai, X., Shiraishi, H., Dontha, N., Luo, D., and Farias, P. 1996. Peptide nucleic acid probes for sequence-specific 
DNA biosensors. J. Am. Chem. Soc. 118: 7667.

5. Wang, J., Nielsen, P., Jiang, M., Cai, X., Fernandez, J.R., Grant, D., Ozsoz, M., Begleiter, A., and Mowat, M. 1997. Mismatch-sensitive hybridization detection by peptide nucleic acids immobilized on a quartz crystal microbalance QCM. Anal. Chem. 69: 5200.

6. Arlinghaus, H.J., Kwoka, M., and Jacobson, K. 1997. Analysis of biosensor chips for identification of nucleic acids. Anal. Chem. 69: 3747.

7. Castro, A. and Williams, J. 1997. Single-molecule detection of specific nucleic acid sequences in unamplified genomic DNA. Anal. Chem. 69: 3915.

8. Jensen, K., Orum, H., Nielsen, P.E., and Norden, B. 1997. Kinetics for hybridization of peptide nucleic acids (PNA) with DNA and RNA studied with the BIAcore Technique. Biochem. 36: 5072.

9. Wang, J., Fernandes, J., and Kubota, L. 1998. Polishable and renewable DNA hybridization biosensors. Anal. Chem. 70: 3699.

10. Fojta, M., Vetterl, V., Tomschik, M., Nielsen, P.E., Wang, J., and Palecek, E. 1997. Adsoprtion of peptide nucleic acid and DNA decamers at electrically charged surfaces. Biophysical J. 72: 2285.

11. Weiler, J., Gausephohl, H., Hauser, N., Jensen, O., and Hoheisel, J. 1997. Hybridization based DNA screening on peptide nucleic acid (PNA) oligomer arrays. Nucleic Acids Res. 25: 2792.

12. Nielsen, P.E. 1999. Peptide Nucleic Acids: Protocols and Applications. Horizon Scientific Press, Wymondham, U.K.

13. Nielsen, P.E., and Egholm, M. 1999. An introduction to peptide nucleic acid. Current Issues Molec. Biol. 1: 89-104. 


\section{Further Reading}

Caister Academic Press is a leading academic publisher of advanced texts in microbiology, molecular biology and medical research. Full details of all our publications at caister.com

- MALDI-TOF Mass Spectrometry in Microbiology Edited by: M Kostrzewa, S Schubert (2016) www.caister.com/malditof

- Aspergillus and Penicillium in the Post-genomic Era Edited by: RP Vries, IB Gelber, MR Andersen (2016) www.caister.com/aspergillus2

- The Bacteriocins: Current Knowledge and Future Prospects Edited by: RL Dorit, SM Roy, MA Riley (2016)

www.caister.com/bacteriocins

- Omics in Plant Disease Resistance Edited by: V Bhadauria (2016) www.caister.com/opd

- Acidophiles: Life in Extremely Acidic Environments Edited by: R Quatrini, DB Johnson (2016) www.caister.com/acidophiles

- Climate Change and Microbial Ecology: Current Research and Future Trend

Edited by: J Marxsen (2016)

www.caister.com/climate

- Biofilms in Bioremediation: Current Research and Emerging Technologies

Edited by: G Lear (2016)

www.caister.com/biorem

- Microalgae: Current Research and Applications Edited by: MN Tsaloglou (2016) www.caister.com/microalgae

- Gas Plasma Sterilization in Microbiology: Theory, Applications, Pitfalls and New Perspectives Edited by: H Shintani, A Sakudo (2016) www.caister.com/gasplasma

- Virus Evolution: Current Research and Future Directions Edited by: SC Weaver, M Denison, M Roossinck, et al. (2016) www.caister.com/virusevol

- Arboviruses: Molecular Biology, Evolution and Control Edited by: N Vasilakis, DJ Gubler (2016) www.caister.com/arbo

- Shigella: Molecular and Cellular Biology Edited by: WD Picking, WL Picking (2016) www.caister.com/shigella

-Aquatic Biofilms: Ecology, Water Quality and Wastewater Treatment

Edited by: AM Romaní, H Guasch, MD Balaguer (2016)

www.caister.com/aquaticbiofilms

- Alphaviruses: Current Biology

Edited by: S Mahalingam, L Herrero, B Herring (2016)

www.caister.com/alpha

- Thermophilic Microorganisms

Edited by: F Li (2015)

www.caister.com/thermophile
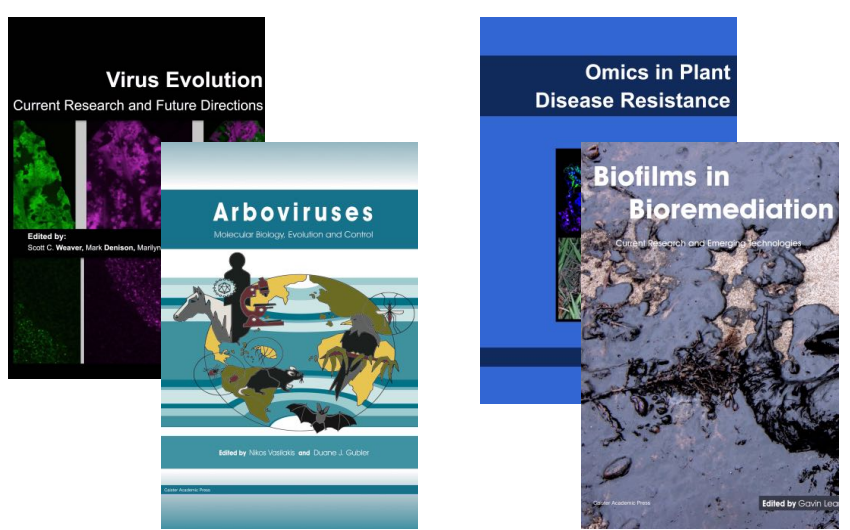
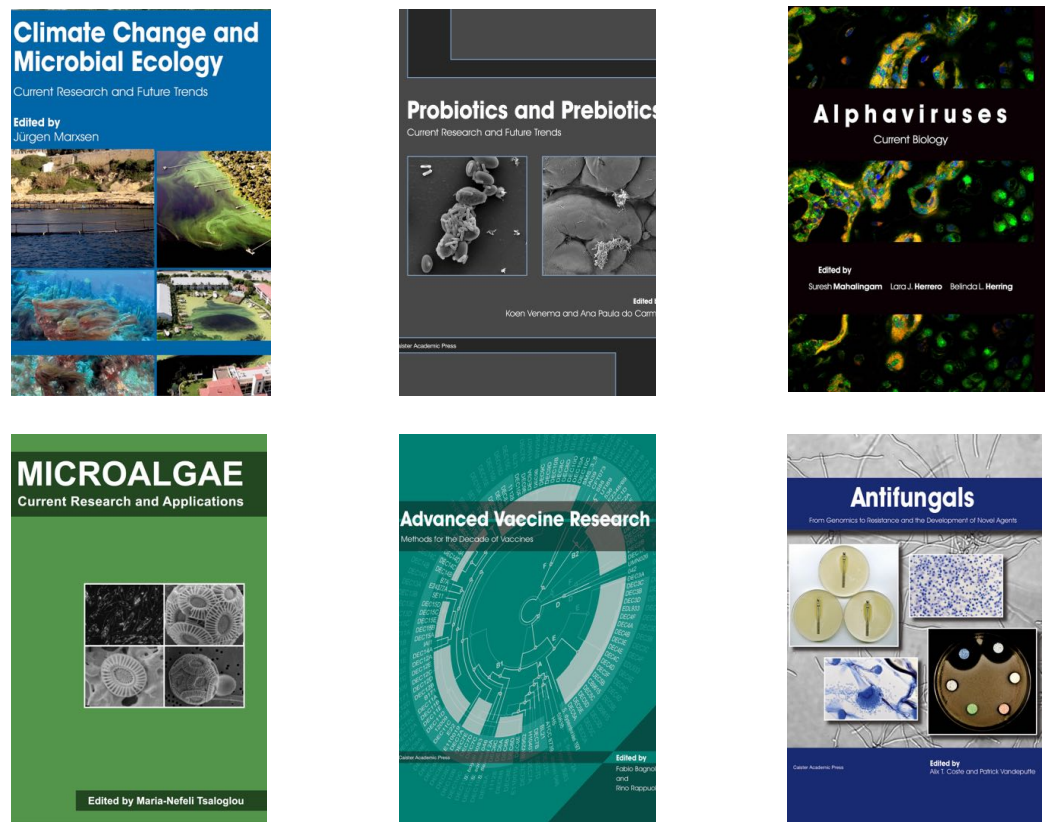

- Flow Cytometry in Microbiology: Technology and Applications Edited by: MG Wilkinson (2015) www.caister.com/flow

- Probiotics and Prebiotics: Current Research and Future Trends Edited by: K Venema, AP Carmo (2015) www.caister.com/probiotics

- Epigenetics: Current Research and Emerging Trends Edited by: BP Chadwick (2015) www.caister.com/epigenetics2015

- Corynebacterium glutamicum: From Systems Biology to Biotechnological Applications

Edited by: A Burkovski (2015)

www.caister.com/cory2

- Advanced Vaccine Research Methods for the Decade of Vaccines

Edited by: F Bagnoli, R Rappuoli (2015)

www.caister.com/vaccines

- Antifungals: From Genomics to Resistance and the Development of Novel Agents

Edited by: AT Coste, P Vandeputte (2015)

www.caister.com/antifungals

- Bacteria-Plant Interactions: Advanced Research and Future Trends Edited by: J Murillo, BA Vinatzer, RW Jackson, et al. (2015) www.caister.com/bacteria-plant

\section{- Aeromonas}

Edited by: J Graf (2015)

www.caister.com/aeromonas

- Antibiotics: Current Innovations and Future Trends

Edited by: S Sánchez, AL Demain (2015)

www.caister.com/antibiotics

- Leishmania: Current Biology and Contro Edited by: S Adak, R Datta (2015) www.caister.com/leish2

- Acanthamoeba: Biology and Pathogenesis (2nd edition) Author: NA Khan (2015)

www.caister.com/acanthamoeba2

- Microarrays: Current Technology, Innovations and Applications Edited by: Z He (2014)

www.caister.com/microarrays2

- Metagenomics of the Microbial Nitrogen Cycle: Theory, Methods and Applications

Edited by: D Marco (2014)

www.caister.com/n2 